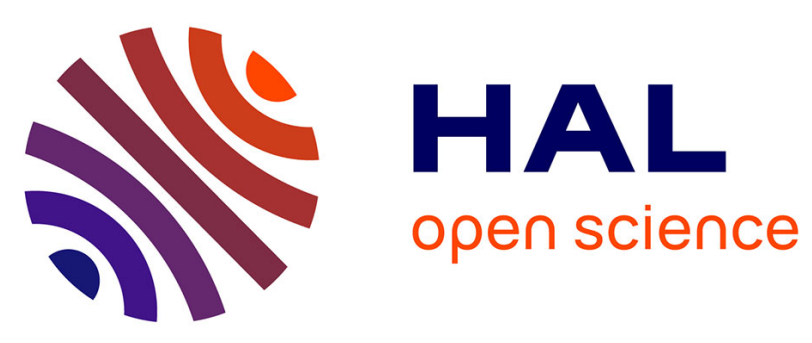

\title{
Dual Signaling System with an Extended-Tetrathiafulvalene-Phenanthroline Dyad Acting as an Electrooptical Cation Chemosensor
}

Marie Hardouin-Lerouge, Bertrand Chesneau, Magali Allain, Piétrick

Hudhomme

\section{To cite this version:}

Marie Hardouin-Lerouge, Bertrand Chesneau, Magali Allain, Piétrick Hudhomme. Dual Signaling System with an Extended-Tetrathiafulvalene-Phenanthroline Dyad Acting as an Electrooptical Cation Chemosensor. Journal of Organic Chemistry, 2012, 77 (5), pp.2441-2445. 10.1021/jo300101c . hal03344627

\section{HAL Id: hal-03344627 \\ https://univ-angers.hal.science/hal-03344627}

Submitted on 15 Sep 2021

HAL is a multi-disciplinary open access archive for the deposit and dissemination of scientific research documents, whether they are published or not. The documents may come from teaching and research institutions in France or abroad, or from public or private research centers.
L'archive ouverte pluridisciplinaire HAL, est destinée au dépôt et à la diffusion de documents scientifiques de niveau recherche, publiés ou non, émanant des établissements d'enseignement et de recherche français ou étrangers, des laboratoires publics ou privés. 


\title{
Dual Signaling System with an Extended-Tetrathiafulvalene- Phenanthroline Dyad Acting as an Electrooptical Cation Chemosensor
}

\author{
Marie Hardouin-Lerouge, Bertrand Chesneau, Magali Allain, and Piétrick Hudhomme* \\ L'UNAM Université, Université d'Angers, Laboratoire MOLTECH-Anjou, CNRS UMR 6200, 2 Bd Lavoisier, 49045 Angers, France
}

Supporting Information
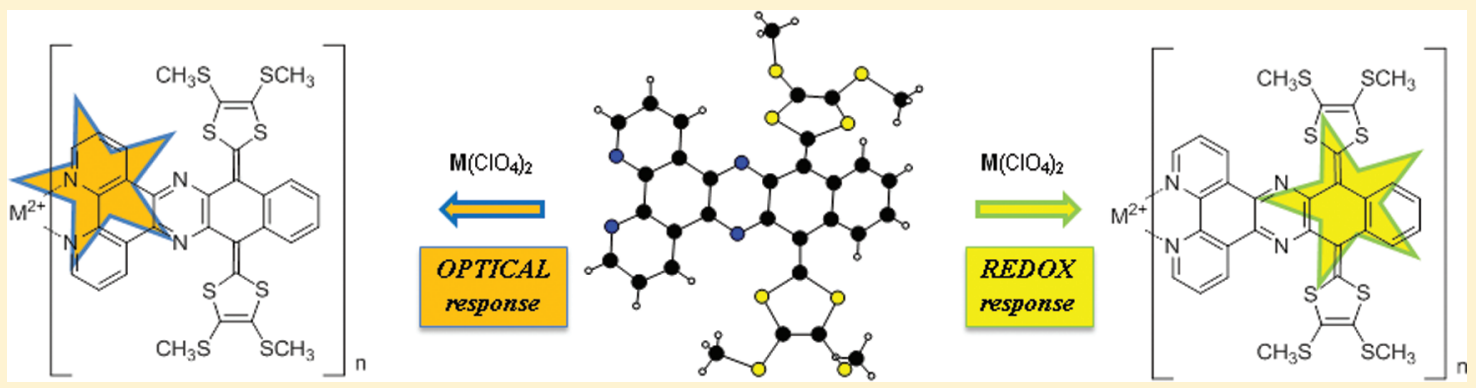

ABSTRACT: An efficient synthesis of unprecedented fused extended-tetrathiafulvalene-dipyridoquinoxaline (exTTF-dpq) dyad is described through the Horner-Wardsworth-Emmons olefination methodology from the dipyrido[3,2-a:2',3'-c]benzo[3,4]phenazine-11,16-quinone (NqPhen) ligand starting material. This exTTF-dpq dyad is demonstrated to act as a dual redox and colorimetric sensor for cations exploiting the proximity between the redox tetrathiafulvalene and the optical phenanthroline detecting sites. Its ability for sensing cations from the d-group metal transitions $\left(\mathrm{Fe}^{2+}, \mathrm{Ni}^{2+}\right.$, and $\left.\mathrm{Zn}^{2+}\right)$ and also with varied cations such as $\mathrm{Ca}^{2+}$ and $\mathrm{Pb}^{2+}$ is presented.

\section{INTRODUCTION}

The development of chemosensors capable of recognizing cationic or anionic species has attracted much attention in recent years within the generalized area of supramolecular chemistry because of their fundamental role in biological and chemical processes. ${ }^{1}$ In the search for applications in fields of very high impact, such as molecular recognition and sensors, the synthesis of multichromophoric architectures is of particular interest. ${ }^{2}$ Moreover, the challenge for developing new ligands capable of color changes upon complexation are particularly attractive in terms of materials applications. Multisignaling sensors that utilize independent optical and electrochemical output signals are known to display special anion affinities, ${ }^{3}$ but corresponding materials for cation recognition are still rare. Ferrocene-based ligands constitute a very popular family of electroactive receptors for sensing cations through a modification of the oxidation potential of the $\mathrm{Fe}^{2+} / \mathrm{Fe}^{3+}$ redox couple. ${ }^{4}$ It was recently shown that the association of ferrocene to a 1,10 phenanthroline (Phen) unit in a ferrocene-imidazophenazine dyad leads to a multichannel chemosensor for $\mathrm{Pb}^{2+}$ and $\mathrm{Hg}^{2+}$ cations. 5

Tetrathiafulvalene (TTF) also presents a remarkable $\pi$-electron donor ability which notably results in two sequential and reversible oxidation processes, affording cation radical $\left(\mathrm{TTF}^{\bullet+}\right)$ and dication $\left(\mathrm{TTF}^{2+}\right)$ species. $^{6}$ Recently, intensive work has been carried out to exploit the TTF framework as a supramolecular signaling and switching unit. ${ }^{7}$ On the other hand, aromatic and heterocyclic nitrogen-based chelating units constitute well-adapted opticalresponsive ligands for metal ion sensing, with a particular interest devoted to the Phen ligand. ${ }^{8}$ Moreover, the chelating capability of the Phen platform can be exploited to reach metal complexes exhibiting UV-vis NIR luminescent properties with investigation of energy/electron-transfer process. ${ }^{9}$ The association of a TTF derivative to the nitrogen-donor chelating ligand Phen is still rare. ${ }^{10}$ TTF and Phen units have been assembled through a macrocycle able to recognize different cations $\left(\mathrm{Cu}^{+}, \mathrm{Ag}^{+}, \mathrm{Li}^{+}\right)$ when part of (pre)catenate complexes. ${ }^{11}$ More recently, TTF has been integrated into fused donor-acceptor dyads involving Phen ${ }^{12}$ or dipyridophenazine (dppz). ${ }^{13}$ The latter TTF-dppz dyad provided a suitable Phen coordination site, and the addition of $\mathrm{Fe}^{2+}$ or $\mathrm{Zn}^{2+}$ cations provokes a color change from purple to blue. $^{13 a}$

TTF with extended $\pi$-conjugation (exTTF) such as $p$-quinodimethane analogues of TTF are characterized by enhanced $\pi$-electron donor properties relative to TTF. ${ }^{14}$ The characteristic one-stage two-electron oxidation process results from reduced intramolecular Coulombic repulsion in the oxidized states thus stabilizing the cationic species. ${ }^{15}$ To our knowledge, exTTF has never been associated to a heterocyclic $\mathrm{sp}^{2}$ nitrogen-donor chelating ligand. On this ground, this work has focused on dyad exTTF-dpq 1 based on the redox-active

Received: January 13, 2012

Published: February 2, 2012 
Scheme 1. Synthesis of the exTTF-dpq Dyad<smiles>O=C1c2ccccc2C(=O)c2nc3c4cccnc4c4ncccc4c3nc21</smiles>

Nqphen

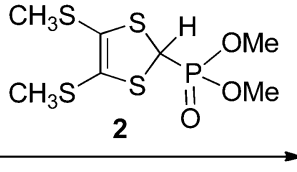

BuLi, THF

$-78^{\circ} \mathrm{C} \rightarrow$ r.t.

$50 \%$ yield<smiles>CSC1=C(C)SC(=c2c3ccccc3c(=C3SC(S)=C(SC)S3)c3nc4c5cccnc5c5ncccc5c4nc23)S1</smiles>

exTTF-dpq 1
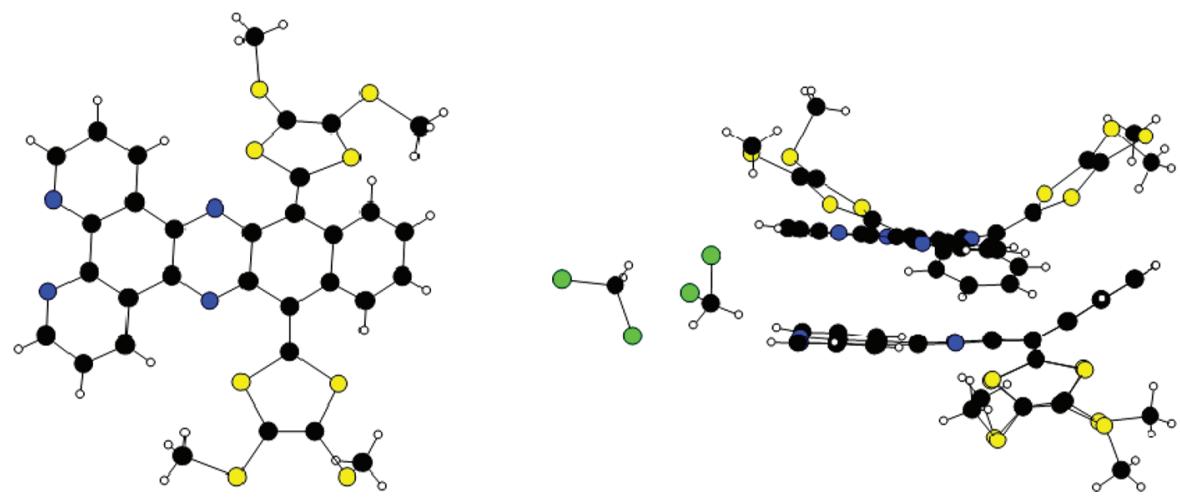

Figure 1. Left: X-ray crystallographic representation of one of the two independent molecules of exTTF-dpq dyad 1. Right: dimerization along the $c$ axis between two molecules.
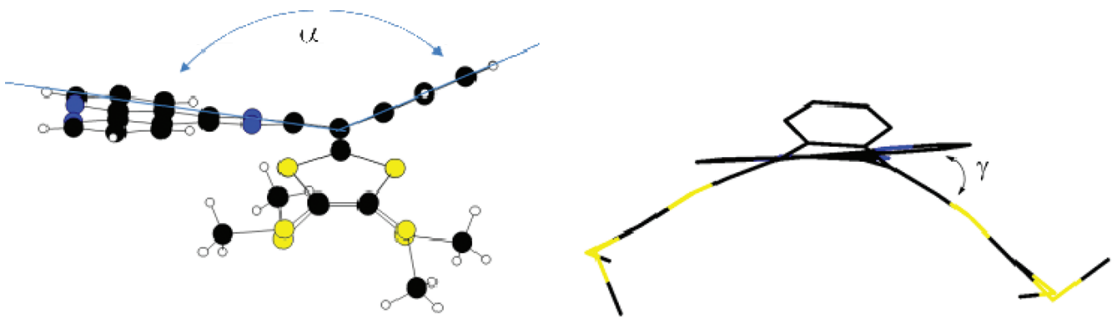

Figure 2. Distortion of the molecule defined by the angles $\alpha$ and $\gamma$.

electron donor exTTF and the dipyrido[3,2-f:2',3'-h]-quinoxaline (dpq) moiety containing a Phen ligand as the electron acceptor. This dyad was expected to show a particular ability for sensing cations through independent electrochemical and optical output signals strongly favored by the proximity of both optical and electrochemical sensing sites.

\section{RESULTS AND DISCUSSION}

Dyad exTTF-dpq 1 was synthesized by applying the HornerWadsworth-Emmons (HWE) reaction using the anion phosphonate generated from compound $2^{16}$ on the acceptor $\mathrm{NqPhen}$ for which we recently described an improved preparation (Scheme 1). ${ }^{17}$

The molecular structure of dyad 1 was determined by X-ray diffraction study. Compound 1 crystallizes as a 4:3 dichloromethane solvate, and the asymmetric unit contains two independent molecules. Moreover, two phenanthroline are stacked by dimerization along the $c$ axis and are separated by a distance of $3.43 \AA$ (Figure 1).

The exTTF moiety of the dyad exhibits a boat conformation of the central quinodimethane ring providing a butterfly-shaped conformation. ${ }^{18}$ This distortion from planarity can be described in terms of the angles $\alpha$ and $\gamma$. The angle $\alpha$ formed by outer aromatic rings, i.e., the "wings of the butterfly", presents a value close to $150^{\circ}$ (Figure 2). This distortion is caused by the steric repulsion between the dithiole sulfur atoms and the perihydrogen atoms according to the $\mathrm{S} \cdots \mathrm{H}$ distances with values between 2.49 and $2.57 \AA$ which have to be compared with the sum of the corresponding van der Waals radii $(2.91 \AA) .{ }^{19}$ Nevertheless, this distortion is minimized due to important $\mathrm{S} \cdots \mathrm{N}$ interactions with distances between 2.66 and $2.72 \AA$ which are shorter than the sum of their van der Waals radii $(3.42 \AA) .{ }^{20}$ The other consequence of these different $S \cdots H$ repulsions and $S \cdots \mathrm{N}$ interactions concerns the tilting of the dithiole units, which is defined by the angle $\gamma$ with values in the range from 20 to $35^{\circ}$ (Supporting Information).

The binding and recognition abilities of dyad $\mathbf{1}$ toward various cations $\left(\mathrm{Fe}^{2+}, \mathrm{Ni}^{2+}, \mathrm{Ca}^{2+}, \mathrm{Pb}^{2+}, \mathrm{Zn}^{2+}\right)$ in the form of their perchlorate salts were evaluated by UV-vis spectroscopy and cyclic voltammetry using optical and electrochemical responses of phenanthroline and exTTF, respectively.

Titration experiments were carried out in $\mathrm{CH}_{2} \mathrm{Cl}_{2}$ by monitoring the changes in the UV-vis spectrum of dyad 1 upon addition of the cation species. A dramatic color change 
from orange to Bordeaux was observed for each cation exposed to dyad 1 (Figure 3). Upon addition of $\mathrm{Fe}\left(\mathrm{ClO}_{4}\right)_{2}$, the

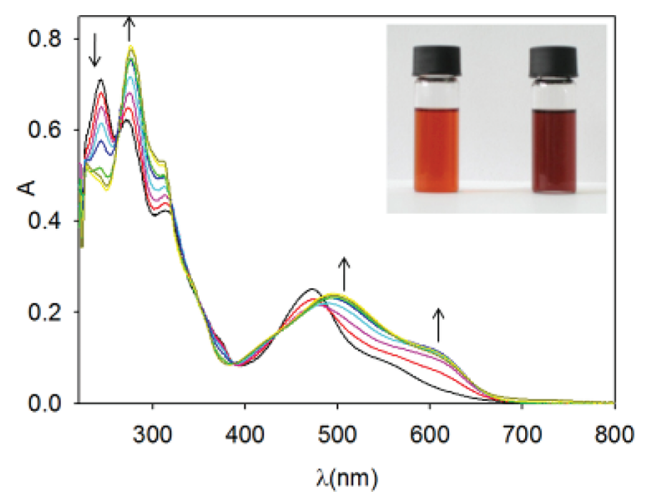

Figure 3. Absorption of dyad $1\left(10^{-5} \mathrm{M}\right.$ in $\left.\mathrm{CH}_{2} \mathrm{Cl}_{2}\right)$ as a function of $\mathrm{Fe}^{2+}$ concentration. The inset shows the samples of 1 (left) and $(1)_{3} \mathrm{Fe}$ (right) in $\mathrm{CH}_{2} \mathrm{Cl}_{2}$.

intraligand band at the $470 \mathrm{~nm}$ maximum absorption decreased and well-defined isosbestic points were observable with the concomitant appearance of new bands at 492 and $600 \mathrm{~nm}$. The first bathochromically shifted band could be assigned to the metal-to-ligand charge transfer (MLCT) absorption band $\left(\mathrm{d}-\pi^{*}\right) .{ }^{21}$ The second band could be ascribed to the intraligand charge-transfer (ILCT) transition with the exTTF acting as the donor and the dpq-Fe ${ }^{\text {II }}$ subunit as the acceptor.

Quantitative measurements of cation affinity were performed by monitoring the changes in the UV-vis spectra at $472 \mathrm{~nm}$ or at $600 \mathrm{~nm}$ of sensor 1 upon addition of cation. A saturation was observed after the addition of approximatively 0.3 equiv in agreement with the formation of the octahedric $(1)_{3} \mathrm{Fe}^{2+}$ complex. The dependence of the absorbance at $600 \mathrm{~nm}$ toward $\mathrm{Fe}^{2+}$ concentration (Job's plot) definitely confirms this stoichiometry with a maximum centered at a molar ratio of 0.7 (Figure 4). Similar profiles for the UV-vis spectra were

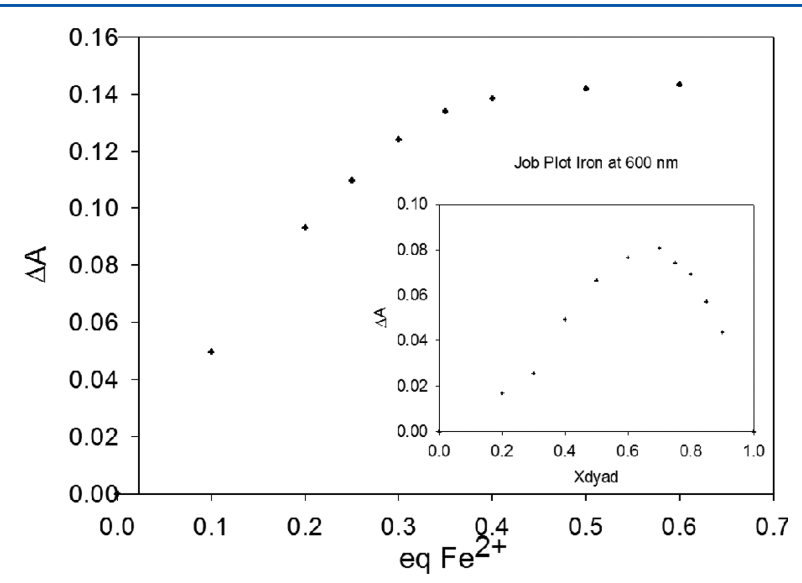

Figure 4. Plots of absorbance at $600 \mathrm{~nm}$ for 1 upon addition of iron(II) perchlorate. Inset: Job's plot analyses at $600 \mathrm{~nm}$ confirming the 3:1 stoichiometry.

observed upon titration of dyad 1 with a saturation around 0.3 equivalent for $\mathrm{Ni}^{2+}, \mathrm{Ca}^{2+}, \mathrm{Zn}^{2+}$, and $\mathrm{Pb}^{2+}$ cations. From Job's plot analyses, these spectral changes were also ascribed to the formation of 1:3 complexes (Supporting Information).
The second signal output was validated by using cyclic voltammetry in order to follow the cation binding by sensor 1 (Figure 5). Cyclic voltammetry in $\mathrm{CH}_{2} \mathrm{Cl}_{2}$ showed that dyad 1
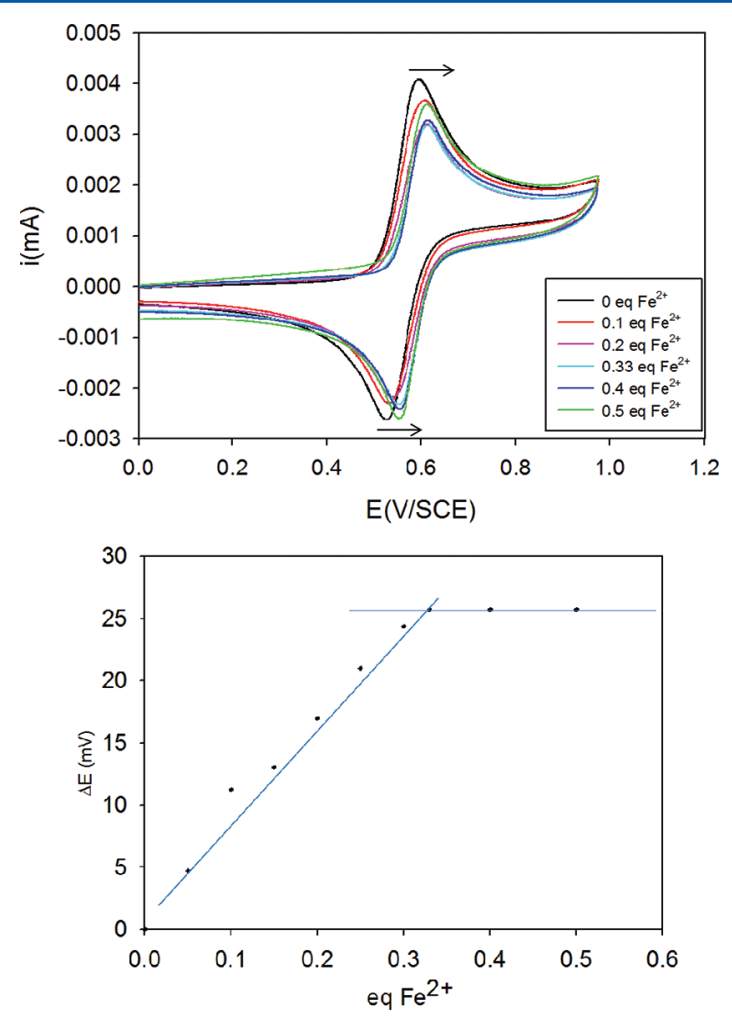

Figure 5. Voltammograms of dyad 1 in a $\mathrm{CH}_{2} \mathrm{Cl}_{2} / \mathrm{CH}_{3} \mathrm{CN}$ (9:1) solution $\left(5 \times 10^{-4} \mathrm{M}\right)$ using $\mathrm{Bu}_{4} \mathrm{NPF}_{6}(0.1 \mathrm{M})$ as the supporting electrolyte as a function of $\mathrm{Fe}^{2+}$ concentration (top). Plot of the shift of the potential $E_{1}{ }^{\text {ox }}$ with added equivalents of $\mathrm{Fe}\left(\mathrm{ClO}_{4}\right)_{2}$ (bottom).

exhibited a quasi-reversible two-electron oxidation wave at $E_{1}{ }^{\text {ox }}=+0.56 \mathrm{~V}$ (vs SCE). The progressive addition of aliquots of metal salts resulted in a positive shift of the two-electron oxidation wave of ex-TTF with $\Delta E$ in the range from 20 to $35 \mathrm{mV}$ for a 0.3 equivalent of $\mathrm{Fe}^{2+}, \mathrm{Ni}^{2+}, \mathrm{Ca}^{2+}, \mathrm{Pb}^{2+}$, and $\mathrm{Zn}^{2+}$ cations. The cation coordination leads to a significant change in redox potential with an anodic shift due to the fact that the sensor-cation complex is more difficult to oxidize. Such a voltammetric response on the two-electron oxidation wave was previously exploited only in the case of crown ether derivatives of 9,10-bis(1,3-dithiol-2-ylidene)anthracene for sensing metal cations. ${ }^{22}$

In conclusion, the results presented herein demonstrate that an original donor-acceptor dyad with extended-TTF and phenanthroline-based ligand can display efficient sensing ability toward metal cations. The detection process can be performed through both optical and electrochemical measurements, thus exploiting the proximity of the donor and acceptor parts. This dual optical-electrochemical chemosensor could be used as well as for d-group metal transitions $\left(\mathrm{Fe}^{2+}, \mathrm{Ni}^{2+}\right.$, and $\mathrm{Zn}^{2+}$ cations) but also with varied cations such as $\mathrm{Ca}^{2+}$ and $\mathrm{Pb}^{2+}$. These results pave the way for developing efficient multifunctional molecular materials which could allow the complexation of cations in aqueous solution thanks to the versatility of the synthesis which allows the introduction of hydrophilic groups on the 1,3-dithiole moieties. 


\section{EXPERIMENTAL SECTION}

The following chemicals were obtained commercially and were used without any purification. Thin-layer chromatography (TLC) was performed on aluminum sheets coated with neutral aluminum oxide $60 \mathrm{~F}_{254}$. Column chromatography of dyad 1 was carried out on deactivated neutral alumina [deactivation by addition of $\mathrm{H}_{2} \mathrm{O}(7 \mathrm{~g})$ in neutral aluminum oxide $50-200 \mu \mathrm{m}(100 \mathrm{~g})]$. Chemical shifts in ${ }^{1} \mathrm{H}$ $(500 \mathrm{MHz})$ and ${ }^{13} \mathrm{C}(125 \mathrm{MHz}) \mathrm{NMR}$ spectra are reported as $\delta$ values in ppm using the residual peak of the solvent as an internal reference.

ExTTF-dpq 1. To a solution of phosphonate $2(910 \mathrm{mg}, 3 \mathrm{mmol})$ (freshly prepared and crystallized using $\mathrm{CH}_{2} \mathrm{Cl}_{2}$ /petroleum ether as a mixture of solvents) in anhydrous THF $(40 \mathrm{~mL})$ under nitrogen atmosphere was added dropwise at $-78{ }^{\circ} \mathrm{C} n$-BuLi $2.5 \mathrm{M}$ in hexane $(1.32 \mathrm{~mL}, 3.3 \mathrm{mmol})$. After the solution was stirred for $15 \mathrm{~min}$ at $-78{ }^{\circ} \mathrm{C}$, compound $\mathrm{NqPhen}$ was added as a solid and by small fractions $(108.6 \mathrm{mg}, 0.3 \mathrm{mmol})$. The reaction mixture was allowed to stand at room temperature under stirring for $24 \mathrm{~h}$. After addition of methanol $(20 \mathrm{~mL})$, the solvent was concentrated under vacuum. The residue was purified by a first chromatography on deactivated neutral alumina using $\mathrm{CH}_{2} \mathrm{Cl}_{2}$ then $\mathrm{CH}_{2} \mathrm{Cl}_{2} / \mathrm{CH}_{3} \mathrm{OH}(4 / 1 \mathrm{~V} / \mathrm{V})$ as eluents. A second chromatography on deactivated neutral alumina using $\mathrm{CH}_{2} \mathrm{Cl}_{2}$ / $\mathrm{CH}_{3} \mathrm{OH}(9 / 1 \mathrm{~V} / \mathrm{V})$ as eluent afforded compound 1, which was isolated in a $50 \%$ yield $(104 \mathrm{mg})$ as a Bordeaux powder after precipitation using $\mathrm{CH}_{2} \mathrm{Cl}_{2}$ and petroleum ether as a mixture of solvents. ${ }^{1} \mathrm{H} \mathrm{NMR}\left(\mathrm{CD}_{2} \mathrm{Cl}_{2}\right.$, $500 \mathrm{MHz}) \delta: 9.15(\mathrm{~m}, 2 \mathrm{H}) ; 7.80\left(\mathrm{dd}, 1 \mathrm{H},{ }^{3} J=5.5\right.$ and $\left.9.5 \mathrm{~Hz}\right) ; 7.71(\mathrm{dd}$, $1 \mathrm{H},{ }^{3} J=5.5$ and $\left.13.5 \mathrm{~Hz}\right) ; 7.38\left(\mathrm{dd}, 1 \mathrm{H},{ }^{3} J=5.5\right.$ and $\left.9.5 \mathrm{~Hz}\right) ; 2.44$ (s, 3H); $2.41(\mathrm{~s}, 3 \mathrm{H}) .{ }^{13} \mathrm{C}$ NMR $\left(\mathrm{CD}_{2} \mathrm{Cl}_{2}, 125 \mathrm{MHz}\right) \delta: 151.0,146.2$, 145.1, 143.2, 134.4, 133.7, 131.9, 131.7, 127.4, 127.3, 126.2, 124.7, 124.2, 119.1, 19.7, 19.2. MS MALDI/TOF (dithranol, $\mathrm{CH}_{2} \mathrm{Cl}_{2}$ ) m/ $\mathrm{z}: 718$ $\left(\mathrm{M}^{+}\right)$. HR-MS (ESI): calcd for $\mathrm{C}_{32} \mathrm{H}_{22} \mathrm{~N}_{4} \mathrm{~S}_{8}=\left(\mathrm{M}^{\bullet+}\right)$ 717.96046, found 717.96097; calcd for $\mathrm{C}_{32} \mathrm{H}_{23} \mathrm{~N}_{4} \mathrm{~S}_{8}=(\mathrm{M}+\mathrm{H})^{+}$718.96829, found 718.96667. Anal. Calcd for $\mathrm{C}_{32} \mathrm{H}_{22} \mathrm{~N}_{4} \mathrm{~S}_{8}$ (719.06): C, 53.45; H, 3.08; N, 7.79. Found: C, 53.22; H, 3.17; N, 7.92.

X-ray single-crystal diffraction data were collected at $293 \mathrm{~K}$ on a diffractometer equipped with a graphite monochromator utilizing Mo $\mathrm{K} \alpha$ radiation $(\lambda=0.71073 \AA)$.

Crystallographic data for 1: $\mathrm{C}_{131} \mathrm{H}_{94} \mathrm{Cl}_{6} \mathrm{~N}_{16} \mathrm{~S}_{32}, M=3130.84$, Bordeaux prism, $0.25 \times 0.22 \times 0.07 \mathrm{~mm}^{3}$, triclinic, space group $P-1, a=12.564(2) \AA ̊ ., b=15.406(4) \AA ̊, c=19.363(3) \AA ̊, \alpha=89.76(2)^{\circ}$, $\beta=80.24(1)^{\circ}, \gamma=79.32(2)^{\circ}, V=3628.3(12) \AA^{3}, Z=1, \rho_{\text {calc }}=$ $1.433 \mathrm{~g} / \mathrm{cm}^{3}, \mu($ Mo K $\alpha)=0.633 \mathrm{~mm}^{-1}, F(000)=1606, \theta_{\min }=2.13^{\circ}$, $\theta_{\max }=26.04^{\circ}, 52931$ reflections collected, 13877 unique $\left(R_{\mathrm{int}}=0.063\right)$, parameters $/$ restraints $=857 / 0, \mathrm{R} 1=0.1342$ and $\mathrm{wR} 2=0.3237$ using 9114 reflections with $I>2 \sigma(I), \mathrm{R} 1=0.1799$ and $\mathrm{wR} 2=0.3510$ using all data, GOF $=1.107,-0.648<\Delta \rho<0.880$ e $\AA^{-3}$. The crystal structure has been deposited at the Cambridge Crystallographic Data Centre and allocated the deposition number CCDC 835842.

\section{ASSOCIATED CONTENT}

\section{S Supporting Information}

Experimental procedures, characterization data, and electrochemical and UV-visible titration results. This material is available free of charge via the Internet at http://pubs.acs.org.

\section{AUTHOR INFORMATION}

\section{Corresponding Author}

*E-mail: pietrick.hudhomme@univ-angers.fr.

\section{Notes}

The authors declare no competing financial interest.

\section{ACKNOWLEDGMENTS}

This work was supported by the French National Research Agency in the frame of the program ANR PNANO entitled TTF-based Nanomat. We thank the Ministère de la Recherche et Technologies for Ph.D. grants to M.H.-L. and B.C.

\section{REFERENCES}

(1) (a) Lehn, J.-M. Supramolecular Chemistry: Concepts and Perspective: VCH: Weinheim, 1995. (b) Steed, J. W. Atwood, J. L. in Supramolecular Chemistry, 2nd ed.; John Wiley \& Sons Ltd.: New York, 2009; Chapter 3, 105-222.

(2) (a) de Silva, A. P.; Gunaratne, H. Q. N.; Gunnlaugsson, T.; Huxley, A. J. M.; McCoy, C. P.; Rademacher, J. T.; Rice, T. E. Chem. Rev. 1997, 97, 1515-1566. (b) de Silva, A. P.; McClenaghan, N. D. Chem.-Eur. J. 2004, 10, 574-586. (c) Valeur, B.; Leray, I. Inorg. Chim. Acta 2007, 360, 765-774.

(3) (a) Mizuno, T.; Wei, W.-H.; Eller, L. R.; Sessler, J. L. J. Am. Chem. Soc. 2002, 124, 1134-1135. (b) Anzenbacher, P. Jr.; Palacios, M. A.; Jursíková, K.; Marquez, M. Org. Lett. 2005, 7, 5027-5030. (c) Lu, H.; Xu, W.; Zhang, D.; Chen, C.; Zhu, D. Org. Lett. 2005, 7, 4629-4632. (d) Bejger, C.; Park, J. S.; Silver, E. S.; Sessler, J. L. Chem. Commun. 2010, 46, 7745-7747.

(4) (a) Beer, P. D.; Gale, P. A.; Chen, G. Z. Coord. Chem. Rev. 1999, 185-186, 3-36. (b) Molina, P.; Tárraga, A.; Caballero, A. Eur. J. Inorg. Chem. 2008, 3401-3417.

(5) Alfonso, M.; Tárraga, A.; Molina, P. J. Org. Chem. 2011, 76, $939-$ 947.

(6) (a) Bryce, M. R. J. Mater. Chem. 2000, 10, 589-598. (b) Segura, J. L.; Martín, N. Angew. Chem., Int. Ed. 2001, 40, 1372-1409. (c) Yamada, J., Sugimoto, T., Eds.; TTF Chemistry. Fundamentals and Applications of Tetrathiafulvalene; Springer Verlag: New York, 2004. (d) Chem. Rev. Molecular Conductors (Thematic issue), Batail, P. Ed. 2004, 104(11). (e) Bendikov, M.; Wudl, F.; Perepichka, D. F. Chem. Rev. 2004, 104, 4891-4945.

(7) Canevet, D.; Sallé, M.; Zhang, G.; Zhang, D.; Zhu, D. Chem. Commun. 2009, 2245-2269.

(8) (a) Sugihara, H.; Hiratani, K. Coord. Chem. Rev. 1996, 148, 285299. (b) Pina, J.; de Melo, J. S.; Pina, F.; Lodeiro, C.; Lima, J. C.; Parola, A. J.; Soriano, C.; Clares, M. P; Albelda, M. T.; Aucejo, R.; García-España, E. Inorg. Chem. 2005, 44, 7449-7458. (c) Zapata, F.; Caballero, A.; Espinosa, A.; Tárraga, A.; Molina, P. J. Org. Chem. 2008, 73, 4034-4044. (d) Wang, X.; Zheng, W.; Lin, H.; Liu, G.; Chen, Y.; Fang, J. Tetrahedron Lett. 2009, 50, 1536-1538.

(9) Accorci, G.; Listorti, A.; Yoosaf, K.; Armaroli, N. Chem. Soc. Rev. 2009, 38, 1690-1700.

(10) Lorcy, D.; Bellec, N.; Fourmigué, M.; Avarvari, N. Coord. Chem. Rev. 2009, 253, 1398-1438.

(11) (a) Jorgensen, T.; Becher, J.; Chambron, J.-C.; Sauvage, J.-P. Tetrahedron Lett. 1994, 35, 4339-4342. (b) Bang, K. S.; Nielsen, M. B.; Zubarev, R; Becher, J. Chem. Commun. 2000, 215-216.

(12) (a) Keniley, L. K. Jr.; Ray, L.; Kovnir, K.; Dellinger, L. A.; Hoyt, J. M.; Shatruk, M. Inorg. Chem. 2010, 49, 1307-1309. (b) Qin, J.; Hu, L.; Li, G.-N.; Wang, X.-S.; Xu, Y.; Zuo, J.-L.; You, X.-Z. Organometallics 2011, 30, 2173-2179.

(13) (a) Jia, C.; Liu, S.-X.; Tanner, C.; Leiggener, C.; Neels, N.; Sanguinet, L.; Levillain, E.; Leutwyler, S.; Hauser, H.; Decurtins, S. Chem.-Eur. J. 2007, 13, 3804-3812. (b) Goze, C.; Leiggener, C.; Liu, S.X.; Sanguinet, L.; Levillain, E.; Hauser, H.; Decurtins, S. ChemPhysChem 2007, 8, 1504-1512.

(14) (a) Martín, N.; Sánchez, L.; Herranz, M. A.; Illescas, B.; Guldi, D. M. Acc. Chem. Res. 2007, 40, 1015-1024. (b) Wenger, S.; Bouit, P.-A; Chen, Q.; Teuscher, J.; Di Censo, D.; Humphry-Baker, R.; Moser, J.-E.; Delgado, J. L.; Martín, N.; Zakeeruddin, S. M.; Grätzel, M. J. Am. Chem. Soc. 2010, 132, 5164-5169.

(15) (a) Yamashita, Y.; Kobayashi, Y.; Miyashi, T. Angew. Chem., Int. Ed. Engl. 1989, 28, 1052-1053. (b) Bryce, M. R.; Moore, A. J.; Hasan, M.; Ashwell, G. J.; Fraser, A. T.; Clegg, W.; Hursthouse, M. B.; Karaulov, A. I. Angew. Chem., Int. Ed. Engl. 1990, 29, 1450-1452. (c) Martín, N.; Sánchez, L.; Seoane, C.; Ortí, E.; Viruela, P. M.; Viruela, R. J. Org. Chem. 1998, 63, 1268-1279.

(16) Moore, A. J.; Bryce, M. R. Synthesis 1991, 26-28.

(17) Chesneau, B.; Hardouin-Lerouge, M.; Hudhomme, P. Org. Lett. 2010, 12, 4868-4871. 
(18) Bryce, M. R.; Batsanov, A. S.; Finn, T.; Hansen, T. K.; Howard, J. A. K.; Kamenjicki, M.; Lednev, I. K.; Asher, S. A. Chem. Commun. 2000, 295-296.

(19) Rowland, R. S.; Taylor, R. J. Phys. Chem. 1996, 100, 7384-7391.

(20) (a) Yamashita, Y.; Suzuki, T.; Miyashi, T. Chem. Lett. 1989, 1607-1610. (b) Yamashita, Y.; Ono, K.; Tanaka, S.; Imaeda, K.; Inokuchi, H.; Sano, M. J. Chem. Soc. Chem. Commun. 1993, 18031805. (c) Morioka, Y.; Nishida, J.; Fujiwara, E.; Tada, H.; Yamashita, Y. Chem. Lett. 2004, 33, 1632-1633.

(21) (a) Pehkonen, S. Analyst 1995, 120, 2655-2663. (b) Kotova, O.; Comby, S.; Gunnlaugsson, T. Chem. Commun. 2011, 47, 68106812.

(22) Bryce, M. R.; Batsanov, A. S.; Finn, T.; Hansen, T. K.; Moore, A. J.; Howard, J. A. K.; Kamenjicki, M.; Lednev, I. K.; Asher, S. A. Eur. J. Org. Chem. 2001, 933-940. 